\title{
Old Nature's almanac for 1981
}

In early times the beginning of each year was marked by the publication of almanacs intended to chronicle events in the succeeding months. Most of these documents were necessarily blends of fact and fiction. The following, however, is an authentic chronicle of the new year.

January: Bitter weather. President Ronald Reagan (20 January) says at inauguration that "we have nothing to hope for but hope itself", and commits the United States to "making the shuttle work within this decade". Dr William Nirenberg appointed chairman of reconstituted President's Science Advisory Committee. Yugoslavia establishes biotechnology enterprise (capital $\$ 20$ million) with licence to manufacture insulin from "porcine pancreatic tissue". Nature publishes 25-page human mitochondrial DNA sequence. Earthquakes in Tashkent. Mercury and Mars ill-placed for observation.

February: Bitter weather (except in Southern Hemisphere). General Alexander Haig reaffirms opposition to Salt II at Senate confirmation hearings on nomination as US Secretary of State. Mass of neutrino measured at Savannah River reactor experiment as $30 \pm 35$ electron volts; US Department of Energy announces "riddle of Universe all but solved" and President Reagan gives new go-ahead for Clinch River fast reactor. Nature publishes first instalment of DNA sequence of human chromosome 7 (F.Sanger); Unesco announces "emergency meeting" of journals editors (Addis Ababa, 1985) to consider "sequence pollution". Interim report of Swinnerton-Dyer committee on organization of University of London says that university must save money "or face prospect of radical change". Earthquakes in Hellenic arc. Venus and Mars ill-placed for observation.

March: Bitter weather; much flood. American journal Science begins publication of nucleotide sequence of human chromosome 7 (W. (ilbert); Senator William Proxmire announces public hearings on question "Are sequences necessary?". US General Accounting Office recommends that Shuttle Tile Repair Module be adapted as skyscraper window-cleaning machine. Neutrino mass estimated as $50 \pm 55$ electron volts by observation of diffuse ultraviolet background; NASA announces "mystery of Universe now cleared up". British universities told that in future, all students must pay economic fees. General Alexander Haig (at continued Senate hearing) reaffirms opposition to Comprehensive TestBan Treaty. Earthquakes in Caribbean. Mercury, Venus and Mars illplaced for observation.

April: Sakharov writes to announce arrival of Spring in Gor'kii. Nature begins publishing errata to Sanger chromosome 7 sequence. Tanzanian Secretary-General of Addis Ababa conference on sequences calls for extension of terms of reference to include measurement of neutrino mass, and charges that present practices of journal editors discriminate against developing nations. First shuttle flight crew sues NASA over early retirement terms. British Chancellor of Exchequer levies Value Added Tax on university fees, but affirms "monetarism is working". Professor Milton Friedman appointed Companion of Honour. Earthquakes in the Levant. Mercury, Venus and Mars ill-placed for observation.

May: Unseasonable weather. Soviet government accedes to Sakharov's request to be put on trial, but postpones formal charges. $\mathrm{Dr}$ Edward Parkes (chairman, UK University Grants Committee) says "no compelling reason" why British universities should be closed, but confesses anxiety about recurrent grant. Centenary celebrations of British Museum (Natural History) pass off without incident; cladists and opponents silenced by Royal presence. Dr F. Sanger forswears nucleotide sequencing until "somebody decides what to do with the data". President Reagan, by executive order, merges Clinch River and shuttle projects, offering management contract to Government of France. General Haig tells Senate confirmation committee that US Administration will "seek to repeal" Anti-Proliferation Act. Earthquakes in Andes. Mars ill-placed for observation.

June: Bitter weather in Antarctica; much flood elsewhere. Merrison committee on "dual-support system" for UK academic research argues that because academic research has continued even though the system has "long since" broken down, there is no special need of new mechanisms for research support. Proxmire Senate committee condemns sequencing research as "pork-barrel biochemistry" and proposes legislation denying federal funds to institutions defining sequences of "more than 52 contiguous nucleotides". General Haig confirmed as US Secretary of
State after promising to press for early signature of Comprehensive TestBan Treaty and ratification of "upgraded Salt II". Rockwell International (main shuttle contractor) announces development of Shuttle Tile Repair Kit as personal space transport module. Earthquakes in Italy. Mercury and Mars ill-placed for observation.

July: Inclement weather. House of Lords committee on "Science and Government" urges reorganization of UK science with separation of research councils from Department of Education, appointment of minister with reponsibility for science and re-creation of Advisory Council on Scientific Policy. UK biotechnology company Celltech takes licence on Yugloslav insulin process. Committee of Vice-Chancellors and Principals announces "agreement in principle" with British Tourist Board that universities will put facilities and staffs at disposal of tourist industry during future extended long vacations in exchange for commission on tourist receipts; growing anxiety about future of Salford and Aston universities. NIH reaches compromise with Proxmire committee on safeguards procedure for regulation of sequencing work. Eclipse of Sun (31 July) visible in Middle East and central Asia. Mercury ill-placed for observation.

August: Improbable weather. NASA commissions Boeing design of reusable long-distance transport system based on 747 with "orbital operation development capability". US Department of Energy dedicates Clinch River site as "national center" for measurement of neutrino mass. Second Voyager approaches Saturn; Jet Propulsion Laboratory announces that "mankind has learned more about the Solar System in the past month than in the previous twelve". Nature finishes publishing errata to Sanger chromosome 7 sequence (see April). Europe on vacation. Mercury, Mars and Saturn ill-placed for observation.

September: Bitter weather. Sakharov trial postponed. British universities postpone sine die opening of new academic year in plan to avoid shutdown. UK government abolishes posts of chief scientist in government departments, but denies abandonment of Rothschild "customer-contractor" principle, pleading only "further steps in battle against public expenditure". Legality of NIH Advisory Committee on Nucleotide Sequences tested in US Supreme Court; Senator Proxmire agrees to modify bill for fear that "United States will lose out to foreign sequencers". Neutrino mass held "indistinguishable from zero" on basis of tritium decay measurement; Clinch River site re-dedicated as "National Nucleotide Sequence Repository". Mercury, Jupiter and Saturn ill-placed for observation.

October: Bitter weather. Interim shuttle modification programme approved by NASA; US General Accounting Office complains that the Orbitwise Re-entry Module Assembly Kit will leave no room in the cargo bay for payload, and that the decision that the shuttle vehicle itself should be disposable will have "negative economic consequences except in California". UK research councils say in annual reports that they have survived better than feared in worsening economic climate and that abandonment of grant-making is only temporary. Dr J. L. Gowans, Secretary of Medical Research Council, denies at press conference statement attributed to him that "medical research is mostly good luck" (see Nature 1/8 January, p.2); rather, says Gowans, "inspired guesswork". Mercury, Jupiter and Saturn ill-placed for observations.

November: Extremes of climate. Nobel prizes: Medicine, Dr César Milstein (for monoclonal antibodies); Chemistry, Dr Fred Sanger (for a method of sequencing carbohydrate macromolecules); Physics, Professor F. W. Reines (for drawing attention to the problem of the neutrino mass). NIH announce further relaxation of sequencing guidelines; joint NIH-EMBO sequence bank commissions advanced computer design from Rockwell International. No planets ill-placed for observation.

December: Weather mixed. Swinnerton-Dyer report on organization of University of London offers "stark" choice between expulsion of and management by Imperial College; university Senate resolves that changes of function unwelcome to those af fected should not be effected. Vice-chancellors announce British universities will begin academic year once cold weather is ended (to avoid excessive heating bills) and "certainly no later than beginning of tourist season". Boeing claims "synchronous orbit capability" for 747; proposes development programme for returning flying machines to Earth. Proxmire committee begins investigation of "neutrino mass boondoggle". Harvard University converts P3 laboratory to squash-court. Eathquakes in Tashkent. Mercury again ill-placed for observation. 